\title{
Influencia de la activación de un residuo arcilloso de la industria papelera en el comportamiento de matrices de cemento
}

\section{Effect of the activation of a clay-base paper industry by-product on cement matrix behaviour}

\author{
$\underline{\text { M. Frías }}^{(*)}$, E. Sabador(*), S. Ferreiro(*), M. I. Sánchez de Rojas(*), R. García(**) y R. Vigil(**)
}

Recepción/Received: 7-III-07

Aceptación/Accepted: 4-XII-07

Publicado online/Online publishing: 1-XII-08

\section{RESUMEN}

El presente trabajo de investigación aborda la influencia de las condiciones de activación (600-750 ${ }^{\circ} \mathrm{C}$ y $2-5$ horas de permanencia en el horno) de los lodos de papel procedente de la fabricación de papel estucado en el comportamiento reológico, físico y mecánico de las matrices de cementos elaboradas con este tipo de adiciones activas.

Los resultados obtenidos muestran una influencia directa entre las condiciones de activación de la caolinita y el comportamiento posterior de los productos calcinados. Así, en condiciones de activación superiores a $700^{\circ} \mathrm{C}$ se observa una menor actividad puzolánica, tiempo de fraguado más corto, disminución de la trabajabilidad de los morteros mezcla y resistencia mecánica más baja.

Palabras clave: residuo de papel, activación, propiedades, cementos mezcla.

\section{SUMMARY}

The present study addresses variations in the calcination temperature $\left(600-750^{\circ} \mathrm{C}\right)$ and kiln time (two to five hours) applied to activate coated paper waste and their effect on the rheological, physical and mechanical behaviour of cement matrices containing these active additions.

The results obtained showed that the conditions under which kaolinite was activated had a direct effect on the subsequent behaviour of the calcined products. At activating temperatures of over $700^{\circ} \mathrm{C}$, pozzolanic activity and mechanical strength were observed to be lower, setting time shorter and the mortar less workable.

Keywords: paper industry waste, activation, properties, blended cements.

\section{INTRODUCCIÓN}

Desde la segunda mitad del siglo pasado, la industria cementera ha sido pionera en el aprovechamiento de las propiedades en un gran número de materiales (naturales, subproductos y residuos industriales) para ser incorpora-

\section{INTRODUCTION}

Since the second half of the twentieth century, the cement industry has pioneered the use of a substantial number of (natural, as well as industrial by-product and waste) materials as active additions in the manufacture

\footnotetext{
(*) Instituto de Ciencias de la Construcción "Eduardo Torroja", CSIC (Madrid, España).

(**) Universidad Autónoma de Madrid (Madrid, España).
} 
dos como adiciones activas en la fabricación de cementos Portland comerciales (puzolanas naturales, cenizas volantes, humo de sílice, escoria siderúrgica, etc.) (1). Con la entrada en vigor de la norma Europea EN 197-1 (2) se especifica claramente la fabricación de cementos comerciales con la incorporación de puzolana natural calcinada en diferentes proporciones (CEM II/A-Q y CEM II/B-Q).

En esta línea, las investigaciones se están centrando en la familia de los filosilicatos y, más concretamente en el grupo de los minerales de la arcilla. Estos minerales, inertes en principio, presentan una actividad puzolánica considerable cuando se someten a temperaturas comprendidas entre 600 y $900{ }^{\circ} \mathrm{C}$. Este proceso térmico provoca una inestabilidad termodinámica que repercute en una alta actividad puzolánica.

Dentro de estos minerales arcillosos, los trabajos de investigación se centran en la caolinita por ser un mineral abundante en muchos países, incluida España. Este mineral cuando se somete a un proceso térmico controlado se convierte en metacaolinita (MK), producto calcinado con excelentes propiedades como material puzolánico (3-10). Frías y Col (11) mostraron que el MK presenta una actividad puzolánica algo inferior al humo de sílice (HS) y muy superior a la ceniza volante (CV), ambos subproductos industriales ampliamente utilizados en la fabricación de cementos y hormigones.

Debido a que las políticas medioambientales sobre la protección de los espacios naturales son cada vez más estrictas, se está priorizando en la búsqueda de vías alternativas para la obtención de materiales generados desde residuos industriales. Este es el caso de la obtención de caolinita procedente de los residuos industriales obtenidos en la industria papelera.

Los trabajos pioneros llevados a cabo por Pera y Col (12) mostraron la viabilidad de reciclar estos lodos de papel para la obtención de MK en condiciones de activación controladas. Frías y $\mathrm{Col}(13,14)$ demostraron las buenas cualidades de los productos calcinados como materiales con propiedades cementantes, resaltando una actividad puzolánica similar a la del MK obtenido de una caolinita natural, aun cuando existan impurezas de otros componentes tales como caliza, talco, micas, cloritas, etc. (15, 16).

El proceso de transformación de la caolinita a metacaolinita depende principalmente de las condiciones de activación (temperatura y permanencia en el horno), cuya incorrecta aplicación puede producir metacaolines con menores propiedades puzolánicas. Las investigaciones previas llevadas a cabo por Vigil y Col (15) y Sabador y Col (17) indicaban una pérdida de actividad, superficie of commercial Portland cements (natural pozzolans, fly ash, silica fume, blast furnace slag and so on) (1). With the entry into effect of European standard EN-197-1 (2), clear specifications were laid down for the manufacture of commercial cements with different proportions of calcined natural pozzolan (CEM II/A and CEM II/B-Q).

Research in this area focuses on the phyllosilicate family, and more specifically on clay minerals. Initially inert, when subjected to temperatures ranging from 600 to 900 ${ }^{\circ} \mathrm{C}$, such minerals exhibit considerable pozzolanic activity as a result of heat-induced thermodynamic instability.

Research has concentrated more on kaolinite than other clay minerals because of the abundant supply existing in many countries, Spain among them. When subjected to controlled heating, this mineral is converted into metakaolinite (MK), a calcine with excellent pozzolanic properties (3-10). Frías et al. (11) showed that pozzolanic activity is somewhat lower in MK than in silica fume (SF) and much higher than in fly ash (FA), two industrial by-products commonly used in cement and concrete manufacture.

Since environmental policies to protect natural areas are becoming increasingly stricter, priority has been given to alternative routes for obtaining usable materials from industrial waste. This is the case of kaolinite, found in paper industry waste.

Pioneer studies conducted by Pera et al. (12) showed that paper sludge could be recycled to obtain MK under controlled activating conditions. Frías et al. $(13,14)$ reported that calcined products had good cementitious properties and in particular that their pozzolanic activity was comparable to the activity found in MK obtained from a natural kaolinite, even in the presence of impurities such as limestone, talc, micas, chlorites and so forth (15, 16).

The transformation of kaolinite to metakaolinite depends primarily on the activation conditions (temperature and firing time), which, if incorrect, may adversely affect the pozzolanic properties of the resulting metakaolin. Prior studies conducted by Vigil et al. (15) and Sabador et al. (17) indicated a loss of activity and BET specific surface 
específica y cambios en su cinética de reacción a elevada temperatura de calcinación.

El presente trabajo aborda, por primera vez, la influencia de las condiciones de activación de los residuos de lodos de papel procedente de la fabricación de papel estucado en algunos de los aspectos técnicos, poniendo especial atención en el comportamiento reológico y mecánico de los cementos Pórtland elaborados con los diferentes productos activados a $600-750{ }^{\circ} \mathrm{C}$ de temperatura de calcinación y a 2 y 5 horas de permanencia en el horno.

\section{MATERIALES Y METODOLOGÍA DE TRABAJO}

\subsection{Materiales}

\subsubsection{Lodos de papel estucado.}

Los residuos industriales que se estudiaron fueron lodos procedentes de la fabricación de papel estucado, cuya humedad es de un $40-50 \%$, motivo por el cual tuvieron que ser secados en una estufa a $105{ }^{\circ} \mathrm{C}$ durante 24 horas. El residuo está constituido por glomérulos de distintas morfologías de coloración grisácea, debido al proceso de destintado. Los datos químicos obtenidos por FRX del residuo papelero (Tabla 1) ponen de manifiesto que en estos residuos industriales los componentes principales son sílice, alúmina y óxido de calcio. as well as changes in reaction kinetics at high calcination temperatures.

The present study is the first to broach the effect of the conditions for activating coated paper sludge on the performance, and in particular the rheological and mechanical behaviour, of Portland cements containing products activated at $600-750{ }^{\circ} \mathrm{C}$ for two or five hours.

\section{MATERIALS AND WORKING METHODOLOGY}

\subsection{Materials}

\subsubsection{Coated paper sludge}

The industrial waste studied was coated paper sludge, which had to be oven dried at $105^{\circ} \mathrm{C}$ for 24 hours to reduce moisture (40-50\%). This waste consisted of clusters of different shapes and a greyish colour, the result of bleaching. XRF analysis (Table 1) showed that the chief components of this industrial waste were silica, alumina and calcium oxide.

Tabla 1 / Table 1

Composiciones químicas de los materiales de partida. Chemical compositions for starting materials.

\begin{tabular}{|c|c|c|}
\hline $\begin{array}{c}\text { Composición Química / } \\
\text { Chemical Composition }\end{array}$ & $\begin{array}{c}\text { Cemento / Cement } \\
\text { CEM I 42.5 R }\end{array}$ & $\begin{array}{c}\text { Lodo de papel estucado / } \\
\text { art paper sludge }\end{array}$ \\
\hline $\mathrm{SiO}_{2} \%$ & 19.48 & 10.69 \\
\hline $\mathrm{Al}_{2} \mathrm{O}_{3} \%$ & 5.95 & 6.74 \\
\hline $\mathrm{Fe}_{2} \mathrm{O}_{3} \%$ & 2.13 & 0.41 \\
\hline $\mathrm{CaO} \%$ & 62.96 & 24.15 \\
\hline $\mathrm{MgO} \%$ & 1.63 & 0.96 \\
\hline $\mathrm{Na}_{2} \mathrm{O} \%$ & 0.32 & 0.24 \\
\hline $\mathrm{K}_{2} \mathrm{O} \%$ & 1.18 & 0.22 \\
\hline $\mathrm{SO}_{3} \%$ & 2.28 & 0.30 \\
\hline $\mathrm{Cl} \%$ & 0.01 & 0.06 \\
\hline $\mathrm{PPC} /$ L.O.I. \% & 3.02 & 55.71 \\
\hline
\end{tabular}

\subsubsection{Cemento}

El cemento utilizado, para el estudio de las propiedades técnicas de las mezclas, fue un cemento del tipo CEM I 42.5R según la designación de la norma UNE EN 197-1

\subsubsection{Cement}

Spanish and European standard UNE EN 197-1 (2) class CEM I 42.5R cement was used to study the mechanical and rheological properties of the mixes. This type of 
(2). Este tipo de cemento se caracteriza por presentar un contenido en clínker igual o superior al $95 \%$, que puede incorporar hasta un $5 \%$ de otros componentes adicionales. La Tabla 1 incluye también la composición química del cemento utilizado.

\subsection{Calcinación de los lodos de papel estucado}

Para evaluar la influencia que ejercen las condiciones de calcinación en las distintas propiedades de los lodos de papel, se realizaron calcinaciones a temperaturas y tiempos de permanencia en el horno, condiciones que se recogen en la Tabla 2.

Una vez obtenidos los diferentes productos calcinados, se muelen y se tamizan por debajo de $45 \mu \mathrm{m}$.

\subsection{Metodología de la disolución saturada de cal}

Para evaluar la actividad puzolánica de los lodos calcinados se utilizó un método acelerado, tradicionalmente usado por el Grupo de Reciclado de Materiales del Instituto de Ciencias de la Construcción Eduardo Torroja, consistente en poner el material a ensayar en contacto con una disolución saturada de cal a $40{ }^{\circ} \mathrm{C}$ durante el periodo de ensayo. Una vez cumplidos los plazos, se calcula el contenido en $\mathrm{CaO}$ presente en la disolución. Para obtener el valor de la cal fijada, expresado en $\mathrm{mMol} / \mathrm{L}$, es necesario realizar la diferencia entre el contenido en $\mathrm{CaO}$ obtenido para una muestra en blanco y el relativo a la muestra de análisis. Esta metodología está basada, en parte, en el método normalizado de puzolanicidad para cementos puzolánicos (18).

Un estudio comparativo de los resultados obtenidos se llevo a cabo con tres adiciones activas comerciales: Humo de sílice (HS), metacaolín (MC) y ceniza volante (CV).

\subsection{Estudio de las propiedades físico-mecánicas de las nuevas matrices cementantes}

El estudio de la influencia de las condiciones de calcinación en el comportamiento de las matrices de cemento con los productos calcinados se llevo a cabo, sustituyendo un $10 \%$ del cemento Portland por lodo calcinado a diferentes condiciones de calcinación (Tabla 2); las mezclas se designaron con los siguientes códigos: CP10-LPC 1; CP10-LPC 2; CP10-LPC 3; CP10-LPC 4; CP10-LPC 5; CP10-LPC 6; CP10-LPC 7 y CP10-LPC 8.

Según la normativa actual (2), los nuevos tipos de cementos binarios deben ser designados como cementos pórtland con puzolana calcinada y dado que el porcentaje de sustitución del cemento es de un $10 \%$ en masa, su designación sería CEM II/A-Q. cement has a clinker content greater than or equal to $95 \%$, with up to $5 \%$ of additional components. Table 1 also gives the chemical composition of the cement used.

\subsection{Calcination of coated paper sludge}

The sludge was calcined at the temperatures and firing times as shown in Table 2 to assess the effect of calcination conditions on the properties of the material.

The calcines were subsequently ground and sieved to obtain particles smaller than $45 \mu \mathrm{m}$.

\subsection{Saturated lime solution method}

The pozzolanic activity of the calcined sludge was determined with an accelerated method traditionally used by the Eduardo Torroja Institute for Construction Science's Materials Recycling Group, which consists in storing the material to be tested in a pool of saturated lime at $40^{\circ} \mathrm{C}$ for the duration of the trial. The CaO content in the solution is calculated at the end of the test period. The amount of lime fixed, in $\mathrm{mMol} / \mathrm{l}$, is found as the difference in the CaO content between the sample analyzed and a control sample. This method is partially based on the standard pozzolanicity test for pozzolanic cements (18).

The results obtained were compared to the findings for three commercial additions: silica fume (SF), metakaolin (MK) and fly ash (FA).

\subsection{Physical and mechanical properties of the new cementitious matrices}

The effect of calcination conditions on the performance of the cement matrices containing calcined products was tested by replacing $10 \%$ of the Portland cement with calcined sludge prepared under different calcination conditions (Table 2); the cement blends were designated as follows: CP10-LPC 1; CP10-LPC 2; CP10-LPC 3; CP10-LPC 4; CP10-LPC 5; CP10-LPC 6; CP10-LPC 7 and CP10-LPC 8.

According to the existing standards (2), these binary cements must be classified as Portland cements with calcined pozzolan, and since the replacement percentage was $10 \%$ by weight, in this case the class would be CEM II/A-Q. 
Los ensayos de agua de consistencia normal, tiempos de fraguado y estabilidad de volumen se llevaron a cabo según lo dispuesto en la norma UNE-EN 196-3 (19).
The tests to determine the water required for normal consistency, setting time and volume stability were conducted as specified in Spanish and European standard UNE-EN 196-3 (19).

Tabla 2 / Table 2

Designación y condiciones de calcinación.

Designation and calcining conditions.

\begin{tabular}{|c|c|c|}
\hline \multirow{2}{*}{$\begin{array}{c}\text { Designación } \\
\text { Designation }\end{array}$} & \multicolumn{2}{|c|}{$\begin{array}{c}\text { Condiciones de calcinación } \\
\text { Calcined conditions }\end{array}$} \\
\cline { 2 - 3 } & Ta $\left.^{\mathbf{(}} \mathbf{C}\right)$ & $\begin{array}{c}\text { Tiempo (horas) } \\
\text { Time (hours) }\end{array}$ \\
\hline LPC 1 & 600 & 2 \\
\hline LPC 2 & 600 & 5 \\
\hline LPC 3 & 650 & 2 \\
\hline LPC 4 & 650 & 5 \\
\hline LPC 5 & 700 & 2 \\
\hline LPC 6 & 700 & 5 \\
\hline LPC 7 & 750 & 2 \\
\hline LPC 8 & 750 & 5 \\
\hline
\end{tabular}

El ensayo de escurrimiento se realizó de acuerdo a la normativa UNE 83811 EX (20) con un mortero amasado, según lo dispuesto en la norma utilizada para la determinación de resistencias. Este ensayo proporciona una medida de la deformabilidad del mortero cuando se le somete a un esfuerzo, o lo que es lo mismo, su trabajabilidad.

La determinación de resistencias mecánicas de morteros se efectuó de acuerdo a la norma UNE-EN 196-1 (21). Partiendo de los materiales que marca dicha norma, se fabricaron una serie de 3 probetas de dimensiones $4 \times 4 \times 16$ por cada tipo de cemento con una relación agua/masa cementante constante de 0,5 de tal manera que cada valor de resistencia mecánica a flexotracción y a compresión, es un promedio de las roturas realizadas.

\section{RESULTADOS Y DISCUSIÓN}

\subsection{Lodos de papel estucado inicial}

\subsubsection{Caracterización química de los lodos.}

De forma análoga a la caracterización realizada para el lodo de partida, los lodos calcinados fueron caracterizados químicamente por FRX, observándose que estos productos están compuestos principalmente por $\mathrm{SiO}_{2}(20,24-$ $26,22 \%), \mathrm{Al}_{2} \mathrm{O}_{3}(13,11-16,98 \%), \mathrm{CaO}(36,39-47,46 \%)$ y MgO (2,15-2,82\%). El resto de los óxidos presentes se encuentran en un porcentaje menor al $0,9 \%$. El contenido en $\mathrm{SO}_{3}$ de los lodos calcinados está cercano al 0,3\%.
The slump test was conducted as described in Spanish standard UNE 83811 EX (20) on a mortar mixed as specified in the standard used to determine strength. This test measures mortar deformability when subjected to a force or, equivalently, its workability.

Mortar mechanical strength was determined as per Spanish and European standard UNE-EN 196-1 (21). Using the materials prescribed in the standard and a water/binder ratio of 0.5 , a series of three $4 \times 4 \times 16-\mathrm{cm}^{3}$ specimens was prepared for each cement type. The bending and compressive strength values reported here are, then, the mean of tested strength values.

\section{RESULTS AND DISCUSSION}

\subsection{Initial coated paper sludge}

\subsubsection{Chemical characterization of the sludge}

Like the initial sludge, the calcined waste was characterized chemically with XRF. The constituents were found to be primarily $\mathrm{SiO}_{2}$ (20.24-26.22\%), $\mathrm{Al}_{2} \mathrm{O}_{3}$ (13.11-16.98\%), $\mathrm{CaO}(36.39-47.46 \%)$ and $\mathrm{MgO}$ (2.15-2.82\%). None of the other oxides present accounted for more than $0.9 \%$. The $\mathrm{SO}_{3}$ content of the calcined sludge came to around $0.3 \%$. 
Se ha realizado un estudio morfológico de los materiales mediante Microscopio Electrónico de Barrido que lleva acoplado un analizador elemental lo que permite hacer análisis puntuales en superficie (SEM-EDX). El resultado es la aparición de cristales de calcita con geles ricos en calcio que coexisten con láminas hexagonales de metacaolinita y fibras de talco, procedentes del material originario (Figura 1).
Material morphology was studied with a scanning electron microscope fitted with an elemental analyzer for micro-spot analysis of the surface (SEM-EDX). Calcite crystals with calcium-rich gels were identified, alongside laminar hexagonal metakaolinite crystals and talc fibres from the original material (Figure 1).

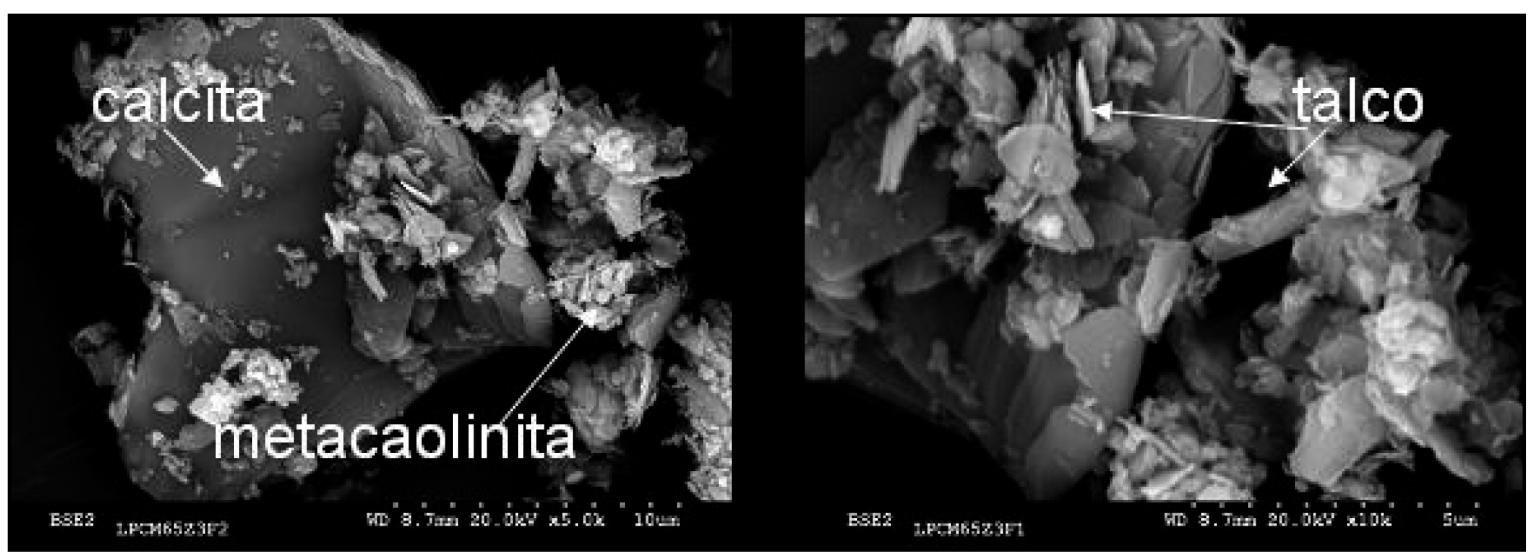

Figura 1. Cristal de calcita recubierto por geles y pequeños cristales pseudohexagonales de metacaolinita (izq). Cristales de talco recubiertos de óxidos de calcio (dcha).

Figure 1. Calcite recovering by gel and pseudohexagonal metakaolinite crystals (left). Talc recovering by calcium oxides (right).

\subsection{Actividad puzolánica}

De los resultados obtenidos mediante la cal fijada $(\mathrm{mMol} / \mathrm{l})$, con el tiempo de reacción (Figura 2) se desprende que todos los productos calcinados presentan actividad puzolánica aunque esta propiedad disminuye al aumentar la temperatura de calcinación. Respecto a la comparación

\subsection{Pozzolanic activity}

The amount of lime fixed at different reaction times (Figure 2) showed that all the calcined products exhibited pozzolanic activity, although the intensity declined with increasing calcination temperatures. The comparison of sludges calcined for two and five hours showed scant dif-

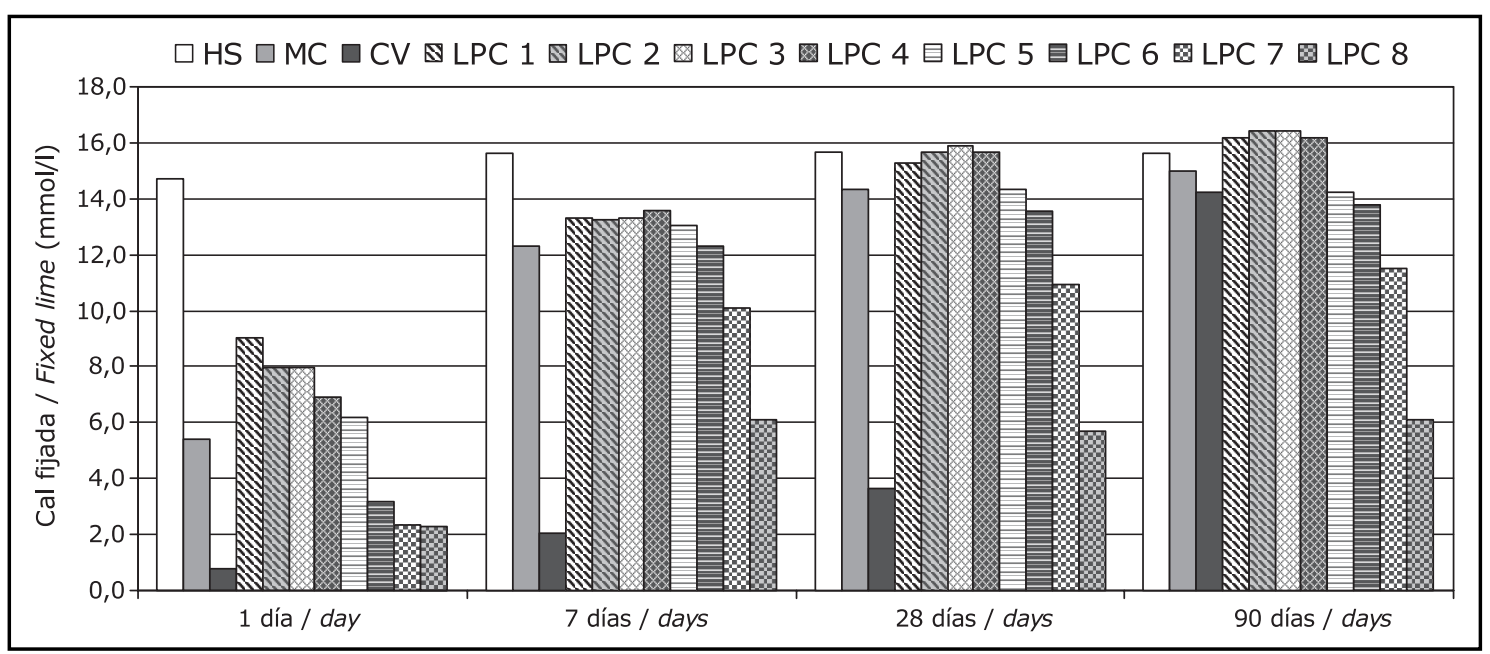

Figura 2. Evolución de la cal fijada.

Figure 2. Fixed lime evolution. 
de los lodos en función del tiempo de permanencia en el horno se puede confirmar que los calcinados a 600 y 650 ${ }^{\circ} \mathrm{C}$ (LPC 1-LPC 4) presentan valores similares de actividad independientemente de la estancia en el horno. Sin embargo, se observa que para los lodos calcinados a 700 y 750 'C (LPC 5- LPC 8), la actividad puzolánica obtenida en las veinticuatro primeras horas de reacción es mayor para los lodos calcinados a 2 horas de permanencia en el horno que para los relativos a 5 horas. Este comportamiento sugiere que la actividad puzolánica de los lodos calcinados está claramente influida por ambas condiciones de activación.

Tal y como se menciona en el apartado 2.3. se llevó a cabo un estudio comparativo de los resultados empleando los dos subproductos industriales normalizados y utilizados habitualmente en la fabricación de cementos comerciales (HS y CV) y el producto procedente de la activación de una caolinita natural (MK).

El contenido de $\mathrm{CaO}$ fijado por el humo de sílice seleccionado para esta investigación desde el inicio de la reacción hasta alcanzar los 7 días es mayor que el fijado por los lodos calcinados. Sin embargo, los lodos calcinados a 600 y $650^{\circ} \mathrm{C}$ durante periodos de 2 y 5 horas, respectivamente, igualan a los 28 días de reacción el contenido en cal fijada e incluso superan dicho valor a partir de los 90 días de reacción.

En el supuesto del uso de metacaolinita se observa que la actividad puzolánica de los lodos calcinados a 600 y $650^{\circ} \mathrm{C}$ a 2 y 5 horas es mayor a partir de las 24 horas de reacción. El resto de los lodos presenta una menor actividad a todas las edades.

Al comparar los datos logrados desde los lodos calcinados y la ceniza volante utilizada en este trabajo, se detecta que para todos los tiempos, los lodos calcinados exhiben mayor actividad puzolánica que las cenizas volantes, a excepción de los calcinados a $750^{\circ} \mathrm{C}$ y 2 y 5 horas de retención en el horno.

\subsection{Evaluación de las propiedades físicas de pas- tas de cemento elaboradas con lodos calcinados}

Se evaluaron la influencia de las condiciones de calcinación sobre el agua de consistencia normal, tiempo de fraguado y estabilidad de volumen de las mezclas elaboradas con cemento y lodo calcinado.

\subsubsection{Propiedades en estado fresco}

Como se puede observar en la Tabla 3, a medida que se aumenta tanto la temperatura como el tiempo de calcinación del lodo, crece el volumen de agua necesario para alcanzar la consistencia normal de las pastas. Además, también se puede indicar que no existen grandes diferen- ferences when the materials were calcined at 600 or $650^{\circ} \mathrm{C}$ (LPC 1-LPC 4). In sludge calcined at 700 or $750^{\circ} \mathrm{C}$ (LPC 5 - LPC 8), however, the 24-hour pozzolanic activity was observed to be higher for two-hour than five-hour calcines, suggesting that the pozzolanic activity of the calcined sludge was clearly affected by both activation conditions.

As noted in item 2.3 above, these results were compared to the findings for two standard industrial by-products commonly used in commercial cement (FS and FA), as well as to the metakaolinite (MK) resulting from activating a natural kaolin.

The CaO fixed by the silica fume selected for this study was higher from the outset and for the first seven days than the amount of lime fixed by the calcined sludge. Nonetheless, the sludge calcined at 600 and $650{ }^{\circ} \mathrm{C}$ for two and five hours, respectively, fixed the same amount of lime as SF after 28 days, and more than the fume after 90 days.

From 24 hours of reaction time onward, pozzolanic activity was greater in the sludge calcined at 600 and $650^{\circ} \mathrm{C}$ for two or five hours than in metakaolinite. Activity was lower in all the other sludges than in metakaolinite at all ages.

All the sludges, except the ones calcined at $750{ }^{\circ} \mathrm{C}$ for two or five hours, exhibited higher pozzolanic activity at all reaction times than the fly ash chosen for this study.

\subsection{Physical properties of cement pastes made with calcined sludge}

Trials were conducted to assess the effect of calcination conditions on the setting time and volume stability of the cement-calcined sludge blends, as well as on the amount of water required for normal consistency.

\subsubsection{Properties of the fresh pastes}

As Table 3 shows, the volume of water needed for normal paste consistency rose with increasing calcination temperature and firing time. The differences found in the amount of water required for normal consistency when the calcination temperature was less than or equal to 650 
cias en los valores de agua de consistencia normal, cuando la temperatura de calcinación de las diferentes adiciones es igual o inferior a $650^{\circ} \mathrm{C}$, y desde el punto de vista del tiempo de permanencia en el horno, 2 ó 5 horas, solo se encuentran diferencias apreciables, cuando la temperatura de calcinación es igual o superior a $700^{\circ} \mathrm{C}$, es decir, para los cementos CP10-LPC 5, 6, 7 y 8, debido a que desde esa temperatura, parte del carbonato cálcico presente en el lodo inicial, inicia su proceso de descarbonatación generando cantidades apreciables de $\mathrm{CaO}(13,22)$.

En cuanto al tiempo de fraguado, se puede indicar que los cementos que incluyen en su composición lodo calcinado exhiben un inicio y fin de fraguado más rápido que el cemento patrón. Este hecho estaría relacionado principalmente con el alto porcentaje de calcita presente en el lodo de papel, la cual produce una reducción en el tiempo de fraguado como una consecuencia de una aceleración en la hidratación de la alita y aluminatos presentes en le cemento anhidro (1).

A pesar de este hecho todos los cementos elaborados con un $10 \%$ de lodo calcinado, cumplen con el requisito impuesto por la norma UNE-EN 197-1 (2), de presentar 60 minutos de tiempo de principio de fraguado, para la clase resistente del cemento original utilizado en la mezcla.

\subsubsection{Estabilidad de volumen}

La Tabla 3 también recoge los valores obtenidos con el ensayo normalizado de estabilidad de volumen. La incorporación de la metacaolinita reciclado de los lodos de papel calcinados no provoca inestabilidad de volumen ya que todas las mezclas de cemento cumplen con la limitación recogida en la normativa vigente $(<10 \mathrm{~mm})$. Los
${ }^{\circ} \mathrm{C}$ were not large, however. Appreciable differences were only observed between sludges with different firing times (two or five hours) when the calcination temperature was greater than or equal to $700{ }^{\circ} \mathrm{C}$, i.e., in cements CP10LPC 5, 6, 7 and 8. Such differences were attributable to the substantial amounts of $\mathrm{CaO}$ generated by the decarbonation taking place at that temperature in part of the calcium carbonate present in the initial sludge $(13,22)$.

The cements with calcined sludge in their composition had earlier initial and final setting times than the control. This was primarily the result of the high percentage of calcite in the paper sludge, which would accelerate alite and aluminate hydration in the anhydrous cement, thereby shortening setting time (1).

Despite this finding, all the cements containing $10 \% \mathrm{cal}-$ cined sludge complied with the 60-minute initial setting time requirement laid down in Spanish and European standard UNE-EN 197-1 (2) for the original cement class used in the blend.

\subsubsection{Volume stability}

Table 3 also gives the standard volume stability test results. The inclusion of recycled metakaolinite from calcined paper sludge did not cause volume instability, inasmuch as all the cement blends met the restriction laid down in the existing codes $(<10 \mathrm{~mm}$ ). Cements CP10LPC 6, 7 and 8 expanded slightly - by one $\mathrm{mm}$ - possibly

Tabla 3 / Table 3

Propiedades físicas de las pastas de cemento con lodo calcinado.

Physical properties of calcined paper sludge blended cement pastes.

\begin{tabular}{|c|c|c|c|c|c|c|}
\hline $\begin{array}{c}\text { Tipo de } \\
\text { cemento / } \\
\text { Type of } \\
\text { cement }\end{array}$ & $\begin{array}{c}\text { Escurrimiento / } \\
\text { Slump (mm) }\end{array}$ & $\begin{array}{c}\text { Agua de } \\
\text { consistencia } \\
\text { normal / } \\
\text { Normal } \\
\text { consistency } \\
\text { water (m) }\end{array}$ & $\begin{array}{c}\text { Tiempo de } \\
\text { principio de } \\
\text { fraguado / } \\
\text { Initial } \\
\text { setting time } \\
\text { (min) }\end{array}$ & $\begin{array}{c}\text { Tiempo de } \\
\text { final de } \\
\text { fraguado/ End } \\
\text { setting time } \\
\text { (min) }\end{array}$ & $\begin{array}{c}\text { Tiempo de } \\
\text { fraguado/ } \\
\text { Setting time } \\
\text { (min) }\end{array}$ & $\begin{array}{c}\text { Estabilidad de } \\
\text { volumen / } \\
\text { Soundness } \\
\text { (mm) }\end{array}$ \\
\hline CP & 190 & 152 & $129 \pm 10$ & $219 \pm 10$ & $90 \pm 10$ & 0 \\
\hline CP10-LPC 1 & 158.25 & 166.5 & $129 \pm 10$ & $219 \pm 10$ & $90 \pm 10$ & 0 \\
\hline CP10-LPC 2 & 158.75 & 167.5 & $119 \pm 10$ & $209 \pm 10$ & $90 \pm 10$ & 0 \\
\hline CP10-LPC 3 & 156.5 & 169 & $119 \pm 10$ & $199 \pm 10$ & $80 \pm 10$ & 0 \\
\hline CP10-LPC 4 & 156.75 & 169.5 & $109 \pm 10$ & $189 \pm 10$ & $80 \pm 10$ & 0 \\
\hline CP10-LPC 5 & 152.25 & 172.5 & $109 \pm 10$ & $189 \pm 10$ & $80 \pm 10$ & 0 \\
\hline CP10-LPC 6 & 141.25 & 175 & $109 \pm 10$ & $189 \pm 10$ & $80 \pm 10$ & 1 \\
\hline CP10-LPC 7 & 138.25 & 181 & $109 \pm 10$ & $179 \pm 10$ & $70 \pm 10$ & 1 \\
\hline CP10-LPC 8 & 133.5 & 190 & $99 \pm 10$ & $179 \pm 10$ & $80 \pm 10$ & 1 \\
\hline
\end{tabular}


cementos CP10-LPC 6, 7 y 8 manifiestan una pequeña expansión de $1 \mathrm{~mm}$, debido, posiblemente, al óxido de calcio procedente de la descarbonatación de la calcita a altas temperaturas, como se ha comentado anteriormente. Bai et al. (22) obtuvieron una expansión de $6 \mathrm{~mm}$, empleando sólo como material hidráulico una ceniza de lodo de papel.

Los resultados obtenidos tanto para el comportamiento reológico como estabilidad de volumen están en consonancia con los valores obtenidos por Vegas y Col. (16) para un lodo calcinado procedente de la fabricación de papel prensa a $700{ }^{\circ} \mathrm{C}$ y 2 horas, cuya composición química y mineralógica es diferente al del lodo a estudio.

\subsection{Evaluación de las consistencias normales y resistencias mecánicas en morteros de cemento mezclados con los lodos calcinados}

Antes del moldeado de las probetas de mortero normalizadas se llevo a cabo la determinación de la consistencia normal de dichos morteros en la mesa de sacudidas de acuerdo con la normativa vigente.

Los resultados obtenidos de este ensayo se recogen en la Tabla 3 y demuestran que, a medida que se aumenta tanto la temperatura como el tiempo de calcinación del lodo, disminuye el escurrimiento de los morteros elaborados con dichos lodos.

Este comportamiento presenta una tendencia inversa a los valores de agua de consistencia normal de las pastas de cemento, lo cual tiene sentido, ya que todos los morteros son preparados con una relación constante de $a / c=0,5$, y si existe mayor demanda de agua de consistencia normal de las pastas según aumenta la temperatura y el tiempo de calcinación, los morteros elaborados con lodos calcinados a mayor temperatura y tiempo de retención, dispondrán de menor cantidad de agua para su trabajabilidad.

Con respecto al comportamiento mecánico de las nuevas matrices, en las Tablas 4 y 5 se recogen los valores tanto de las resistencias a flexotracción como a compresión de las probetas de mortero normalizadas y su evolución con el tiempo de curado.

Se puede indicar para las resistencias a flexotracción, que para un día de curado todas las mezclas muestran una resistencia inferior a la del patrón, y a la vez, disminuyen con el incremento tanto de la temperatura como del tiempo de calcinación. Los menores valores de resistencia podrían estar relacionados tanto con el proceso de descarbonatación de la calcita presente en los lodos de papel de partida como por la disminución de la superficie específica del MK obtenido a altas temperaturas de calcinación (15). due to the calcium oxide resulting from the calcite decarbonation at high temperatures discussed above. Bai et al. (22) reported 6-mm expansion in paper sluldge ash used as the sole hydraulic material in their study.

The above results for rheological behaviour and volume stability were consistent with the values found by Vegas et al. (16) for newsprint sludge (with a different chemical and mineralogical composition from coated paper sludge) calcined at $700^{\circ} \mathrm{C}$ for two hours.

\subsection{Normal consistency and mechanical strength in cement mortars containing calcined sludge}

Before moulding the standardized specimens, the normal consistency of the mortars was determined on a flow table pursuant to the existing standards.

The results obtained, given in Table 3, show that as sludge calcination temperatures and firing times increased, the slump of the respective mortars declined.

While contrary to the trend observed in the water required for normal consistency in cement pastes, this behaviour was logical, for all the mortars were prepared at a constant $w / c$ ratio of 0.5 . If the water demand for normal paste consistency grew with increasing calcination temperature and firing time, the mortars made with sludge calcined at higher temperatures and firing times would have less water available for workability.

Tables 4 and 5, in turn, give the bending and compressive strength values for the standardized mortar specimens at different curing times.

Note that the one-day bending strength was lower in all the blends than in the control, and declined with increasing calcination temperature and firing time. These lower strength values may be attributed to both the decarbonation of the calcite in the initial paper sludge and the decline in the BET specific surface of the MK obtained at high calcination temperatures (15). 
Tabla 4 / Table 4

Resistencias a flexotracción de los morteros mezcla.

Flexural strength of blended mortars.

\begin{tabular}{|c|c|c|c|}
\hline \multirow{2}{*}{$\begin{array}{c}\text { Tipo de cemento / } \\
\text { Type of cement }\end{array}$} & \multicolumn{3}{|c|}{ Resistencias mecánicas a flexotracción / Flexural Strength (MPa) } \\
\cline { 2 - 4 } & 1 día / 1 day & 7 días / 7 days & 28 días / 28 days \\
\hline CP & $6.23 \pm 0.40$ & $8.63 \pm 0.60$ & $9.64 \pm 0.55$ \\
\hline CP10-LPC 1 & $5.01 \pm 0.10$ & $8.05 \pm 0.31$ & $10.20 \pm 0.26$ \\
\hline CP10-LPC 2 & $5.07 \pm 0.15$ & $8.72 \pm 0.44$ & $9.15 \pm 0.38$ \\
\hline CP10-LPC 3 & $4.98 \pm 0.32$ & $8.89 \pm 0.62$ & $9.79 \pm 0.52$ \\
\hline CP10-LPC 4 & $4.92 \pm 0.21$ & $8.15 \pm 0.61$ & $8.50 \pm 0.56$ \\
\hline CP10-LPC 5 & $4.89 \pm 0.44$ & $8.58 \pm 0.40$ & $7.52 \pm 0.55$ \\
\hline CP10-LPC 6 & $4.75 \pm 0.32$ & $8.50 \pm 0.53$ & $7.46 \pm 0.25$ \\
\hline CP10-LPC 7 & $4.09 \pm 0.35$ & $8.11 \pm 0.44$ & $8.98 \pm 0.40$ \\
\hline CP10-LPC 8 & $4.49 \pm 0.36$ & $8.59 \pm 0.36$ & $8.22 \pm 0.46$ \\
\hline
\end{tabular}

A 7 días de curado todos los morteros, incluido el patrón, ostentan resistencias a flexotracción similares, lo cual indica que debe existir una reacción puzolánica entre los días 1 y 7 de curado, entre la metacaolinita aportado por el lodo y la portlandita generada durante la hidratación del cemento, que provoque que las resistencias de las mezclas se equiparen a las del patrón.

Para 28 días de curado, no existe una tendencia clara en los valores de resistencia a flexotracción, pero si se puede observar que cuando la temperatura de calcinación es igual o inferior a $650{ }^{\circ} \mathrm{C}$, estas resistencias se aproximan a los valores del patrón y en algunos casos son superiores.

En cuanto a las resistencias a compresión se puede indicar que para un día de curado el comportamiento observado es el mismo que para las resistencias a flexotracción. Sin embargo, después de 7 días de curado, la mayoría de las mezclas alcanzan valores similares entre sí y superiores al del patrón, excepto para las adiciones calcinadas a $750{ }^{\circ} \mathrm{C}$, lo cual confirma el efecto puzolánico. Esta similitud entre los resultados de resistencia de las diferentes mezclas concuerda con los valores medidos para la actividad puzolánica a 7 días, los cuales son prácticamente idénticos entre sí, excepto para los lodos calcinados a $750{ }^{\circ} \mathrm{C}$ (Figura 2).

Estos resultados son coincidentes con los publicados por Ambroise y Col. (23), demostrando que los morteros fabricados a partir de mezclas de cemento Portland y metacaolinita al 10 y $20 \%$ presentaban, después de 7 días de curado, una resistencia a compresión superior a los fabricados con cemento portland sin adición.

A 28 días de curado, sigue existiendo esta similitud entre las resistencias a compresión y los valores de actividad puzolánica, pero para esta edad de curado la resistencia a
All the seven-day mortars, including the control, showed similar bending strengths, indicating the existence, between the first and seventh day of curing, of a pozzolanic reaction between the metakaolinite from the sludge and the portlandite generated during cement hydration. That reaction raised the blended cement strength to values comparable to the strength observed in the control.

While no clear pattern emerged around the bending strength of 28-day specimens, calcination temperatures of less than or equal to $650^{\circ} \mathrm{C}$ were observed to yield values similar to or even higher than the strength recorded for the control.

Compressive strength in one-day specimens, in turn, followed the same pattern as described above for bending strength, while the pozzolanic effect was confirmed in the seven-day specimens. With the exception of the additions calcined at $750{ }^{\circ} \mathrm{C}$, all the blended cement mixes had similar values and all were higher than in the control. This parallelism between strength values for the different blends is consistent with the seven-day pozzolanic activity values recorded, which were practically identical except in the sludges calcined at $750^{\circ} \mathrm{C}$ (Figure 2).

These findings also concurred with the results published by Ambroise et al. (23), who reported that seven-day mortars made from Portland cement blends containing $10 \%$ and $20 \%$ metakaolinite exhibited higher compressive strength than addition-free mortars.

This similarity between compressive strength and pozzolanic activity continued to be observed in the 28-day specimens, but at this age strength was very similar in the 
compresión es prácticamente similar a la del cemento patrón, excepto para el mortero que incorpora el lodo calcinado a $750{ }^{\circ} \mathrm{C}$, en el cual disminuye considerablemente.

La Tabla 5 también recopila las exigencias de la normativa vigente, para la clase resistente del cemento portland original que se ha utilizado para preparar las mezclas (CP I $42,5 \mathrm{R})$. Los resultados ponen de manifiesto, que la mayoría de los cementos que incorporan lodo calcinado en su composición, sólo necesitan un día de curado para cumplir con la especificación de resistencia para dos días de curado y que los que no alcanzan este valor con un día de curado, están muy próximos a él, y por tanto su evolución en el tiempo garantiza que a dos días de curado cumplirán sobradamente esta especificación. $Y$ atendiendo a la exigencia de resistencia para 28 días, se puede decir que todos los cementos que incorporan lodo calcinado en su composición cumplen con holgura esta especificación. blended and control mortars, except for the mortar with sludge calcined at $750^{\circ} \mathrm{C}$, where it was considerably lower.

Table 5 also gives the existing requirements for the original Portland cement strength class used to prepared the blends (CEM I 42.5 R), which show that after only one day of curing, most of the cements containing calcined sludge met the two-day strength specification. Those that failed to reach such requirement after 24 hours were very close to it and their subsequent evolution guaranteed that after two days they would be amply compliant. Moreover, all the cements containing calcined sludge exhibited strength values far higher than the 28-day requirement.

Tabla 5 / Table 5

Resistencias a compresión de los morteros mezcla. Compressive strength of blended mortars.

\begin{tabular}{|c|c|c|c|}
\hline \multirow{2}{*}{$\begin{array}{c}\text { Tipo de cemento / } \\
\text { Type of cement }\end{array}$} & \multicolumn{3}{|c|}{ Resistencias mecánicas a compresión / Compressive strenght (MPa) } \\
\cline { 2 - 4 } & 1 día / 1 day & 7 días / 7 days & 28 días / 28 days \\
\hline CP & $21.94 \pm 0.78$ & $46.73 \pm 1.59$ & $60.27 \pm 1.32$ \\
\hline CP10-LPC 1 & $20.30 \pm 0.15$ & $48.39 \pm 0.85$ & $62.13 \pm 1.02$ \\
\hline CP10-LPC 2 & $20.65 \pm 0.25$ & $48.58 \pm 0.96$ & $59.69 \pm 0.50$ \\
\hline CP10-LPC 3 & $20.42 \pm 0.77$ & $49.03 \pm 1.42$ & $61.70 \pm 0.79$ \\
\hline CP10-LPC 4 & $19.46 \pm 0.47$ & $48.97 \pm 0.62$ & $58.56 \pm 1.17$ \\
\hline CP10-LPC 5 & $20.33 \pm 0.38$ & $47.19 \pm 0.72$ & $58.41 \pm 1.57$ \\
\hline CP10-LPC 6 & $19.41 \pm 0.32$ & $47.37 \pm 0.70$ & $58.19 \pm 0.67$ \\
\hline CP10-LPC 7 & $17.23 \pm 0.26$ & $46.49 \pm 0.80$ & $54.04 \pm 1.39$ \\
\hline CP10-LPC 8 & $18.50 \pm 0.35$ & $45.84 \pm 0.62$ & $54.24 \pm 0.79$ \\
\hline $\begin{array}{c}\text { Exigencias / } \\
\text { Requirements } \\
\text { UNE-EN 197-1:2005 }\end{array}$ & \multicolumn{2}{|c|}{ 2 días / 2 days $\geq 20.0$} & $42.5 \leq R M C \leq 62.5$ \\
\hline
\end{tabular}

En general, se aprecia que tanto las resistencias a flexotracción como las de compresión disminuyen durante las primeras 24 horas de reacción con respecto al mortero de referencia, debido, principalmente, al efecto de dilución (el cual prevalece sobre el puzolánico), provocado por la sustitución parcial del cemento Portland por la adición activa $(16,24)$. Sin embargo, a edades de hidratación superiores, es el efecto puzolánico el que predomina durante la hidratación, obteniéndose valores de resistencias similares a los de referencia; a excepción de los lodos calcinados a $750^{\circ} \mathrm{C}$.
As a rule, both the bending and compressive strength values were lower than in the control in the first 24 hours due primarily to the dilution effect (which prevails over the pozzolanic effect) occasioned by the partial replacement of Portland cement with the active addition (24). At longer hydration times, however, the pozzolanic effect prevailed during hydration, yielding values similar to the control, except in mortars containing sludge calcined at $750^{\circ} \mathrm{C}$. 


\section{CONCLUSIONES}

- Todos los lodos calcinados presentan actividad puzolánica; sin embargo, su evolución varía sustancialmente en función de las condiciones de calcinación.

- De los resultados obtenidos, desde el punto de vista técnico, energético y económico, las mejores condiciones de calcinación para este residuo mineral están comprendidas entre 600 y $700^{\circ} \mathrm{C}$ de temperatura y 2 horas de permanencia en el horno.

- En las condiciones recomendadas, la actividad puzolánica de los lodos calcinados (metacaolinita) es comparable a la del humo de sílice y a la de la metacaolinita puro a partir de 7 días de reacción.

- La incorporación de un $10 \%$ en masa de lodo calcinado al cemento Portland modifica ligeramente las propiedades del mismo, aunque cumple todas las exigencias técnicas recogidas en la normativa europea vigente.

\section{AGRADECIMIENTOS}

Los autores agradecen a la Comunidad de Madrid (ref. Proyecto: GR/AMB/0448/2004) por su financiación y también a la empresa Holmen Paper Madrid y al laboratorio STDI (Lafarge, Toledo) por su ayuda a esta investigación.

\section{CONCLUSIONS}

- While all the calcined sludge exhibited pozzolanic activity, the patterns varied substantially depending on the calcination conditions.

- The findings show that from the performance, energy efficiency and economic standpoints, the optimal results are obtained when this mineral waste is calcined at temperatures ranging from 600 to $700{ }^{\circ} \mathrm{C}$ for two hours.

- Under the recommended conditions, after the seventh day the pozzolanic activity of calcined sludge (metakaolinite) was comparable to activity in silica fume and pure metakaolinite.

- The inclusion of $10 \%$ of calcined sludge by weight to Portland cement modified cement properties slightly, but met all the technical requirements laid down in existing European standards.

\section{ACKNOWLEDGEMENTS}

The present study was funded by the Regional Government of Madrid (Project ref.: GR/AMB/0448/2004). The authors wish to thank Holmen Paper Madrid and the (Lafarge-Asland) STDI Laboratory for their assistance in this research.

\section{BIBLIOGRAFÍA / BIBLIOGRAPHY}

(1) Taylor, H. F. W.: Cement Chemistry, p. 436, Thomas Telford Publishing, Tomas Telford Services Ltd, 2a Edición, Londres, 1997.

(2) UNE EN 197-1:2005: "Cemento. Parte 1: Composición, especificaciones y criterios de conformidad de los cementos comunes".

(3) Cabrera, J. G. and Nwaubani, S. O.: "Strength and chloride permeability of concrete containing red tropical soils", Magazine of Concrete Research, vol. 45, no 164 (1993), pp. 169-178.

(4) Wild, S., Khatib, J. M., and Jones, A.: "Relative strength, pozzolanic activity and cement hydration in superplasticised metakaolin concrete", Cem. Concr. Res., vol. 26, n. 10 (1996), pp. 1537-1544. http://dx.doi.org/10.1016/0008-8846(96)00148-2

(5) Palomo, A., Blanco, M. T., Granizo, M. L., Puertas, F., Vázquez, T. and Grutzeck, M. W.: "Chemical stability of cementitious materials based on metakaolin". Cem. Concr. Res., vol. 29 (1999), pp. 997-1004. http://dx.doi.org/10.1016/S0008-8846(99)00074-5

(6) Talero, R.: "Performance of metakaolin and Portland cements in ettringite formation as determined by ASTM C 452-68: Kinetic and morphological differences", Cem. Concr. Res., vol. 35, (2005), pp. 1269-1284. http://dx.doi.org/10.1016/j.cemconres.2004.10.002

(7) Frías, M. and Sánchez de Rojas, M. I.: "Influence of the metakaolin on porous structure of matrices based in MK/cement", Mater. Construcc., vol. 50, nº. 259 (2000), pp. 57-68.

(8) Frías, M.: "The effect of MK on the reaction products and microporosity in blended cement pastes submitted to long hydration time and high curing temperature", Adv. Cem. Res., vol.18, nº.1(2006), pp. 1-6. http://dx.doi.org/10.1680/adcr.2006.18.1.1

(9) Lima, P. S., and Dal Molin, D. C.: "Viability of using calcined clays, from industrial bu products, as pozzolans of high reactivity", Cem. Concr. Res., vol. 35 (2005), pp. 1993-1998. http://dx.doi.org/10.1016/j.cemconres.2005.04.012

(10) Ahmadi, B. and Al-khaja., W.: "Utilization of paper waste sludge in the building construction industry", Res. Conser. Recl., vol. 32 (2001), pp. 105-113. http://dx.doi.org/10.1016/S0921-3449(01)00051-9

(11) Frías, M., Sánchez de Rojas, M. I. and Cabrera, J.: "The effect that the pozzolanic reaction of metakaolin has on the heat evolution in MK-cement mortars", Cem. Concr. Res., vol. 30, no. 2 (2000) 209-216. http://dx.doi.org/10.1016/S0008-8846(99)00231-8

(12) Pera, J. and Amrouz, A.: "Development of highly reactive metakaolin form paper sludge", Adv. Cem. Bas. Mater., no. 7 (1998), pp. $49-56$.

(13) Frías, M., Sánchez de Rojas, M. I. and Rivera, J.: "Influence of calcining conditions on pozzolanic activity and reaction kinetics in paper sludge-calcium hydroxide mixes", V.M.. Malhotra (Ed.), 8th CANMET/ACI International Conference on fly ash, silica fume, slag and natural pozzolans in concrete, Las Vegas, 2004, pp. 879-886. 
(14) Frías, M., Sánchez de Rojas, M. I., Rodríguez, O., García, R. and Vigil, R.: "Characterization of calcined paper sludges as environment friently source of MK for manufacture of cementing matrices". Adv. Cem. Res., Vol. 20, no 1 (2008), pp. 23-30. http://dx.doi.org/10.1680/ adcr.2006.18.1.1

(15) Vigil, R., Frías, M., Sánchez de Rojas, M. I., Vegas, I. and García, M.: " Mineralogical and morphological changes of clacined paper sludge at different temperaturas and retention in furnace", Applied Clay Science, vol. 36, no. 4 (2007), pp. 279-286.

(16) Vegas, I., Frías, M., Urreta, J. y San José, J. T.: "Obtención de una adición puzolánica a partir de la calcinación controlada de lodos de destintado de papel: estudio de las prestaciones en matrices de cemento", Mater. Construcc., vol. 56, no. 283 (2006), pp. 49-60.

(17) Sabador, E., Frías, M., Sánchez de Rojas, M. I., Vigil, R., García, R. y San José, J. T.: "Caracterización y transformación de un residuo industrial (lodo de papel estucado) en un material con propiedades puzolánicas". Mater. Construcc., vol. 57, no. 285 (2007), pp. 45-59.

(18) UNE-EN 196-5:2006, "Métodos de ensayo de cementos. Parte 5: Ensayo de puzolanicidad para cementos puzoláncios".

(19) UNE-EN 196-3:2005, "Métodos de ensayo de cementos. Parte 3: Determinación del tiempo de fraguado y de la estabilidad de volumen".

(20) UNE 83811:1992 EX, "Métodos de ensayo. Morteros frescos. Determinación de la consistencia. Mesa de sacudidas (Método de referencia)".

(21) UNE-EN 196-1:2005, "Métodos de ensayo de cementos. Parte 1: Determinación de resistencias mecánicas".

(22) Bai, J., Chaipanich, A., Kinuthia, J. M., O'Farrell, M., Sabir, B. B., Wild, S. and Lewis, M. H.: "Compressive strength and hydration of wastepaper sludge ash-ground granulated blastfurnace slag blended pastes", Cem. Concr. Res., vol. 33 (2003), pp. 1189-1202. http://dx.doi.org/10.1016/S0008-8846(03)00042-5

(23) Ambroise, J., Murat, M. and Pera, J.: "Hydration reaction and hardening of calcined clays and related minerals: V. Extension of the research and general conclusions". Cem. Concr. Res., vol. 15, no. 2 (1985), pp. 941-947.

(24) Frías, M. and Sánchez de Rojas, M. I.: "The effect of high curing temperature on the reaction kinetics in MK/lime and MK-blended cement matrices at $60{ }^{\circ} C^{\prime \prime}$, Cem. Concr. Res., vol. 33 (2003), pp. 643-649. http://dx.doi.org/10.1016/S0008-8846(02)01040-2 
